\title{
Development of the Banking System in Kyrgyzstan: An Historical Review and Current Challenges
}

Dastan ASEINOV (https://orcid.org/0000-0001-9264-1419), Department of Finance and Banking, KyrgyzTurkish Manas University, Kyrgyzstan; e-mail: dastan.aseinov@manas.edu.kg

Kamalbek KARYMSHAKOV (http://orcid.org/0000-0002-6839-9498), Department of Finance and Banking, Kyrgyz-Turkish Manas University, Kyrgyzstan; e-mail: kamalbek.karymshakov@manas.edu.kg

\section{Kırgızistan'da Bankacılık Sisteminin Gelişimi: Tarihsel İnceleme ve Güncel Sorunlar}

\begin{abstract}
Banking in transition economies differs from developing and developed economies with market system. This study aims to review development of the banking system in Kyrgyzstan since independence. The period under consideration is divided into five stages, each of which has a main distinctive aspect. Despite considerable achievements in last fifteen years the banking system still remains vulnerable to external shocks. Moreover, insufficient institutional infrastructure is one of the fundamental factors retarding further development of the banking system.

Keywords : Banking System, Transition Economies, Kyrgyzstan, Financial Infrastructure.

JEL Classification Codes : $\quad$ G21, N20, P21, P33.

\section{$\ddot{\mathbf{O} z}$}

Geçiş ekonomilerinde bankacılık faaliyeti, piyasa sistemi gelişmekte olan ve gelişmiş olan ülkelerden farklılık göstermektedir. Bu çalışmada Kırgızistan'da bağımsızlıktan sonraki dönemde bankacılık sisteminin gelişiminin incelenmesi amaçlanmaktadır. Araştırılan dönem bankacılık sisteminin gelişme aşamalarındaki farklılıklarına göre beş alt döneme ayrılarak ele alınmıştır. Son onbeş yılda kaydedilen önemli başarılara rağmen bankacılık sistemi halen dış şoklara karşı savunmasız kalmaktadır. Ayrıca, kurumsal altyapının yetersizliği bankacılık sisteminin daha da geliştirilmesini geciktiren temel faktörlerden biri olmuştur.
\end{abstract}

Anahtar Sözcükler $\quad$ : $\quad$ Bankacılık Sistemi, Geçiş Ekonomileri, Kırgızistan, Finansal Altyapı. 


\section{Introduction}

Economic development necessitates availability of financial resources for investment activities. The main element of this process is banking system. Development of banking system in developing countries is conditional to different structural issues ranging from low savings to weak prudential norms. In 1990s transition economies faced more challenging issues, since creation and development of financial system required implementation of comprehensive economic reforms.

Kyrgyzstan as one of the transition economies implemented radical and comprehensive structural reforms. However, post-reforms general economic performance has not been strong and remained sensitive to external shocks. Evolution of the banking system has been conditioned by the general macroeconomic trends. Recent economic slowdown in Eurasian countries and exchange rate volatility issues has posed several challenges for both commercial banks and National Bank of Kyrgyz Republic (henceforth, NBKR). In perspectives, attempts to adopt new regulative strategies by NBKR as response to these issues may be reflected not only in banking regulation norms, but also have implications for general economic policies. Despite the fact that new challenges caused by economic cycles several issues have systematic character and rooted in the period of structural changes of both economy and banking system.

This paper aims to review evolution of banking system in Kyrgyzstan by highlighting major stages up to the current economic conditions. Previous studies provided with review of earlier years of transition and economic recovery stages in the beginning of 2000s (Kloc \& Woodward, 1995; Jenkins, 1996; Kloc, 2002; Sagbansu, 2006). More recent studies focused on the banking system performance through analysis of the basic banking sector statistical data (Vorobey, 2015; Yadav 2016). This study contributes to the literature by extending the review period up to more recent changes and underlining the major feature of each stage of development of the banking system in Kyrgyzstan.

Paper is structured to describe evolution of the banking system in Kyrgyzstan chronologically, which is divided into five periods. Each period is described in the context of particular economic conditions. First period captures period of comprehensive and radical economic reforms. Second period is characterized by instabilities caused by Russian crisis and internal institutional deficiencies in the banking system. Third period takes into account the economic recovery and growth period in the sector up to 2008. Fourth and fifth period cover Global Financial Crisis and impact of external shocks originated from recent instabilities in the region 2014-2016 correspondingly.

\section{Economic Reforms and Banking System: 1991-1997}

Structural economic reforms consisted of the liberalization, macroeconomic stabilization and privatization efforts. Liberalization in its own turn focused on liberalization of prices and remove of the state control over prices, and liberalization of external trade operations. In both of these dimensions Kyrgyzstan performed quick implementation: up to 
1995 almost all prices in the domestic economy were free to be determined by market and Kyrgyzstan became member of WTO by 1997. Analogously, privatization programs were comprehensive and dominant part of state owned enterprises, excluding enterprises in strategic sectors of economy, were privatized during this period. These attempts to introduce market mechanisms were realized under the conditions of macroeconomic instability. Significant decrease of GDP from 1991 to 1995 by about 50 per cent and liberalization of the prices increased inflation rates and unemployment. Restructuring of previous SOEs into new private sector firms were not always successful. Along with general macroeconomic conditions absence of the experience on corporate governance had serious implications not only for establishment of private firms, but also for healthy functioning of newly emerging financial institutions. Implications of these particular specifics of this period for the banking system development are explained below.

\subsection{Transformation Processes and Macroeconomic Instabilities}

As a part of the economy banking system also experienced substantial changes during implementation of rapid neoliberal reforms carried out in the framework of transformation processes to market economic system in 1990's (Jenkins, 1996; Baimyrzaeva, 2011). These reforms had presumed fundamental changes in the operating principles of the banking business in the 1990's Kyrgyzstan. However, several deficiencies made it virtually impossible to successfully implement these reforms (Kloc, 2002: 23).

Before these reforms there was banking system of Kyrgyz Soviet Socialist Republic which was a part of centralized banking system of USSR (Mullineux, 1988: 163-164). The centralized banking system consisted of republican branches of Gosbank (The State Bank) in each union republic and subordinated specialized banks. This banking system served as a mean of administrative execution of monetary transactions for financing government budget and investments of state enterprises, and mobilization of savings of households according to detailed financial plan adjusted to achieve goals of government's central economic plan (De Melo \& Denizer, 1999: 21; Johnson, 2000; Berglof \& Bolt, 2002).

Soviet banking system had not market-oriented objectives, enough capacity and experience on supervision and regulation in market economy. The Soviet Period commercial banks did not have independence in their activities, and clients of those banks were not allowed freedom in their choice of a bank. There were not cost minimisation or/and profit maximisation incentives in these banks (Garvy, 1977: 33; Kloc \& Woodward, 1995: 74; Zoli, 2001: 5; Fries \& Taci, 2005: 56). Their function in the economy was limited by channelling directed credits to state enterprises which also lasted during early stages of tranformation. These credits allocated among enterprises for their inputs and investments according to government's central economic plan authorized by central government, rather than on risk analysis and repayment ability of borrowers (Mullineux, 1988: 163; De Melo \& Denizer, 1999: 20-21; Berglof \& Bolton, 2002: 78-79; Sagbansu, 2006: 42). All these deficiencies inherited from Soviet-period banking system considerably impeded the successful financial intermediation activities of Kyrgyz banks in 1990's (Kloc, 2002: 21). 
Large proportion of non-performing loans in portfolio of commercial banks which had been accumulated through imprudent credit policy and lax lending culture inherited from soviet period during the early years of transition often appeared to be reason for bank failures. Worsened loan portfolio of the banking sector was one of the main issues of banking system in 1990's (Kloc \& Woodward, 1995; Jenkins, 1996; Tang et al, 2000: 7; Uyanik \& Segni, 2001: 102). Along with this hyperinflation caused by liberalization of prices, interest and foreign exchange rates, crisis in Ruble zone and uncontrolled money supply, and transformation processes appeared as central macroeconomic problem for banking system (Abazov, 1999; Kloc, 2002: 15).

\subsection{Lending Quality, "Soft" Loans and Non-Performing Loans (NPL)}

As above mentioned in Soviet period banks channeled directed loans, which mainly received by large state enterprises to support production activities in the framework of industry policy of government (De Melo \& Denizer, 1999: 20-21). Enterprises engaged in production were linked to each other's from different Soviet countries and functioned as a unified production system. Collapse of the USSR led to the disintegration not only of this production network, but also integrated banking system functioned in Soviet period (Hare et al., 2000: 24).

These enterprises previously functioned in the integrated production system faced lack of prospects to find markets for their products, since old economic links with enterprises from other post-Soviet countries were disrupted (Sherif et al, 2003: 13). The quality of credit portfolios of commercial banks worsened, since main debtors of banks were members of this production system. Thus in the process of formation market-oriented banking system insolvency problem became apparent. Half of the banks in the country were in this difficult situation.

NBKR attempted to improve the financial situation of enterprises, caused by radical transformation processes by providing concessional "soft" loans to these enterprises. Expansion of these "soft" loans provided by NBKR mainly through former specialized state banks (3-4 largest banks) to state enterprises according to instructions of the Parliament and government were lasted up to beginning of 1994 (Kloc \& Woodward, 1995; Golodniuk, 2005: 7). Despite the reforms carried out from 1991 to 1993 these credits allocated for specific purposes or to specific sectors (agricultural sector and manufacturing industries) of the economy remained as main source of commercial banks' loanable funds instead of deposits. Cutting of allocating "soft" loans to enterprises in 1994 futher detoriated the economy. Which in turn worsened the quality of banks' loan portfolio (Kloc \& Woodward, 1995; Zoli, 2001: 5; Aslund, 2007: 121-122).

Over the next years most of these "soft" loans had emerged as non-performing loans. It was mainly due to the old (central planning system) management style (Kloc \& Woodward, 1995: 91; Jenkins, 1996: 17; Kloc, 2002: 21; Bonin \& Watchel, 2003: 2), imprudent credit policy and lax lending culture inherited from soviet period (Ruziev \& Majidov, 2013: 685), lack of adequate modern domestic experience in construction, banking 
supervision, and legal regulation of market-oriented banking system (Jumabaeva, 2000: 46; Gegenheimer, 2006); poor professional skills of managers, sub-standard internal audit (Jumabaeva, 2000: 48) in banking system. Except "soft" loans, deficiencies of institutional infrastructure and deep deterioration of the macroeconomic environment provoke an increase of NPLs which caused the instabilities in the banking sector in subsequent years.

\subsection{Bankruptcy of Banks and Decreasing Confidence}

Eventually, commercial banks were not able to repay "soft" credits to NBKR. Then, since the beginning of 1995, provision of "soft" credits to commercial banks halted by NBKR. Cutting off main source of funds and lasting recession left the commercial banks in a difficult position (Kloc \& Woodward, 1995: 91). In that situation, banks were forced to offer higher deposit rates that later increased obligations to their depositors and higher interest rates for loans.

Simultaneously to this hyperinflation caused by crisis in Ruble zone, fall in production and rising of prices of imported goods in previous years led to declining of real income and savings of population, deposit withdrawals which in turn resulted as exceeded interest rates (\%250-270) and shortness of lending terms (3-6 months). Besides them a sharp increase in the exchange rates and interest rates following their liberalization, introduction of national currency in 1993, deficiencies of monetary policy and direct financing state budget deficit led to further deposit withdrawals. All these decreased volume and increased dollarization of both provided loans and attracted deposits by banks (Kloc \& Woodward, 1995: 4; Jenkins, 1996: 5; Abazov, 1999: 214).

In addition to these, attraction of the deposits was problematic because of lack of trust to commercial banks. Bankruptcy of the several banks (including large and systemic banks, Kyrgyzagroprombank, Elbank) after restructuring of banking system in 1995-1996, and after deteriorations related with Russian Crisis and institutional deficiencies (in supervision, prudential regulation, corporate governance, banking auditing) in 1998-2002; and after political and social crisis in 2010 substantially decrease the confidence in banking system of the country (Abazov, 1999: 216; Uyanik \& Segni, 2001: 102; Kloc, 2002: 42; Sherif et al, 2003: 74; Sagbansu, 2006: 40; Brown et al, 2009: 1678). This also triggered deposit attraction by banks in subsequent years.

\subsection{Restructuring Program}

Prudential regulatory requirements, banking supervision procedures, accounting standards implemented in banking sector were improper and not meet international standards (Sherif et al, 2003: 74). Liberal licensing policy, but inexplicit and complicated liquidation systems, low capitalization, related party abuse increased the probability of bank insolvencies (Kloc, 2002: 15-20). In 1995-1997, under consultancy of international financial institutions in the framework of market reforms in financial sector restructuring programs were implemented. These programs significantly improved institutional infrastructure in the banking system (Baimyrzaeva, 2011: 556). 
As a result of these programs Agency on Banks Reorganization and Debt Restructuring DEBRA) was established in 1996. The main objective of this institute was to management, collection and recovery of debt and assets of liquidated banks. In 1997 Kyrgyz Agricultural Finance Corporation were created in order to recovery and collecting of agricultural credits (mainly loans granted by Kyrgyzagroprombank's). Bad assets of banking sector cleaned up through liqudation several sistemic banks (Tang, 2000: 40; Zoli, 2001: 35; Uyanik \& Segni, 2001: 102). Wide range reforms toward restructuring and privatization of state-owned enterprises, including state-owned banks (SOB) contributed to macroeconomic destabilization (Vorobey, 2015).

Accounting system, legislation, supervision and regulation framework, corporate governance and risk management in banking sector had were improved (Tang, 2000: 14; Zoli, 2001: 23). NBKR's independence has been enhanced; licensing policy tightened and entry of foreign capital was occurred (Kloc \& Woodward, 1995: 15; Kloc, 2002: 10). Harmonizing of prudential regulatory requirements for international ones, increasing of minimum capital requairements, introduction of International Accounting Standards in 1997 were other results of FINSAC (Tang, 2000: 14; Uyanik \& Segni, 2001: 102). However, all these were not enough to prevent next deterioration in the sector in 1998-2002.

Implemented restructuring program (FINSAC) aimed strengthening the banking system contributed to solution problems related with problem banks. But, poor internal governance in banks, deficiencies in supervisory framework and prudential regulation contributed to the emergence of instability in the banking sector in 1998-1999 that can be associated with the Kyrgyzgazmunaizat and Russian crisis.

\section{Russian Crisis: 1998-2002}

The underdeveloped institutional infrastructure was emerged as central problem for the weak and small Kyrgyz banking sector in this period (Uyanik \& Segni, 2001: 102; Mitra, 2010: 205; Engvall, 2016). In the 1998-1999 loan portfolios of the Kyrgyz banking sector once again has experienced deterioration, which is rather related with Kyrgyzgazmunaizat and inderctly with Russian crisis (Uyanik \& Segni, 2001: 102; Siegoelbaum et al, 2002: 8; Pastor \& Damjanovic, 2003). Kloc (2002: 7) indicate that contribution of Russian financial and banking crisis on instabilities resulted by bankruptcies of several banks in 1998-1999 were less than internal factors. Therefore, this banking crisis can be specified as special case that considered combination of external and internal factors affected the banking sector.

Affiliation among banks had indicated deficiencies of banking auditing, supervision, regulation, corporate governance, weakness of legal framework and corruption (Uyanik \& Segni, 2001: 102-103; Siegoelbaum et al, 2002: 8). Insufficient corporate governance was strictly related with inefficient lending policies, high concentration of loans, improper monitoring of the loans and misguided policy of paying interest on deposits (Kloc, 2002: 50). Under these conditions quality of loan portfolio of several banks significantly deteriorated. 
As an appearent result of the crisis in this period was liquidation of eight commercial banks in 1998-2001. After liquidation of Merkurii Bank, KyrgyzKramdsBank, Bishkek Bank, Maksat Bank in 1999 and Insan Bank in 2000, liabilities and assets of these banks had been transfered to the newly created state-owned Kairat Bank and DEBRA. Later Kairat Bank was taken over by Kazakh bank (Brown et al, 2009: 1678). Merkurii Bank was almost systemic bank in the banking sector. Large portion of loans of Merkurii Banks had been granted in US dollars to Kyrgyzgazmunaizat, which was the large state enterprise in oil and gas industry (Kloc, 2002: 58).

As consequence of erosion of banking capital caused by inflation and losses of particular banks minimum capital requirement was increased in August 2000. Banking supervision was tightened and regulatory requirements related with safety and soundness have been raised. But only 2 banks complied with this requirement, while majority of commercial banks had liquidity and solvency issues (Uyanik \& Segni, 2001: 103; Siegoelbaum et al, 2002: 67). Radical increase of minimum capital requirement from 25 million soms up to 100 million soms met resistance by particular banks in August 2001 (Kloc, 2002: 7). This resistance led to the fact that the NBKR has lowered the minimum level of capital to 25 million since April 2002.

As a result of these macroeconomic conditions in 1998-1999 Kyrgyzstan national currency som devalued by $\% 55$. This fact increased credit risk of commercial banks. Another problem, dollarization, which is also still one of the main problems of the banking sector, began to manifest itself to a greater extent. However, by the end of 1999 and 2000, currency rate and overall level of prices were stabilized (Uyanik \& Segni, 2001: 102).

High volatility of foreign exchange rates in 1996 and 1998 led to significant dollarization of commercial banks' balance sheet in 2000's. This reduces the effectiveness of monetary policy and increases indirect credit risk, particularly when unhedged borrowers are forced to borrow in foreign currency. Ultimately, increased vulnerability of the country's economy and banking sectors balance sheet to external shocks (Brown et al, 2009; Mitra, 2010: 205; EBRD, 2011: 19; Orozalieva, 2015; Engvall, 2016). Unpredictable monetary policy triggered confidence in som and increased uncertainty.

The NBKR began to actively participate in the interbank foreign exchange market and conduct currency interventions, which allowed the NBKR to regulate the exchange rate and strengthen the confidence in the national currency. On the other hand the monetary policy measures taken by the NBKR aimed at reducing inflation and inflow of foreign currency mainly through international financial assistance contributed to a reduction in demand for foreign currency (NBKR, 2001). NBKR trying to reduce the growing demand for US dollar made interventions in currency market. Despite these measures dollarization remained at high rates (Sagbansu, 2006: 46; Isakova, 2008). 


\section{Recovery and Macroeconomic Stabilization: 2003-2008}

Aftermaths of instability period in 2003-2008 banking sector experienced a period of relative stability and recovery. This period also can be described as a post-crisis period of growth. Statistics indicate that proportion of bad loans of the banking sector relatively to previous years decreased significantly throughout 2003-2008 (Sagbansu, 2006: 52; Struyk \& Roy, 2006). Moreover, improvement of the macroeconomic environment, increase in the inflow of foreign capital into the banking sector, mainly from Kazakhstan also supported these progresses in the banking sector (Pomfret, 2006; Ruziev \& Majidov, 2013: 686; Engvall, 2016).

In 2001-2005, the banking system developed rapidly without any external shocks or internal problems (Vorobey, 2015). Establishment of credit bureau CJSC "Ishenim" in 2003 can be considered as completion of introduction of international standards of accounting, prudential regulation and banking supervision. However, due to political instability in March 2005 risk awareness of commercial banks considerably increased (Met et al, 2008: 6).

Despite the political instability in 2005, banking sector expansion along with economic growth were stable up to the Global Financial Crisis. This was a period of favorable macroeconomic environment and abundant supply of bank credit. It should be noted that one of the fundamental factors of growth of the banking sector in this period was increasing foreign capital. Especially the loan portfolio of banks with foreign capital from Kazakhstan has increased significantly. Almost half of the banking sector's loan portfolio belonged to Kazakh-owned banks. Instability in the banking sector of Kazakhstan in 2007 sharply decreased credit growth in Kyrgyzstan in 2008, while in 2009 credit growth rates completely stopped (Ruziev \& Majidov, 2013: 698).

In that situation, a deposit protection system would enable to increase confidence in banks and subsequently increase the volume of attracted deposits (Kloc, 2002: 58-59; Sagbansu, 2006: 40; Met et al, 2008: 6). After many attempts, in 2008, a deposit insurance system was established with a delay of 9 and 10 years compared to Kazakhstan and Ukraine, respectively. In recent years, by deposit insurance coverage Kyrgyzstan ahead of only two FSU countries, Tajikistan and Moldova (International Association of Deposit Insurers, 2012: 4; Demirgüç-Kunt et al, 2014). More recently, it increased up to 200000 Soms in July of 2016.

\section{Global Financial Crisis and Internal Political Crisis: 2009-2013}

Kyrgyz economy was strongly affected by the increase in food and fuel prices in 2008. Then, effect of global financial crisis on Kyrgyz banking sector appeared in the second half of 2009 (Mitra, 2010: 219; Coleman et al, 2012: 56; Ruziev \& Majidov, 2013: 695). The banking system of Kyrgyzstan is not practically integrated directly with the global or regional financial markets. However, banking system of Kazakhstan is more integrated with both global financial markets and Kyrgyz banking system. Based on this, it can be argued that the banking system of Kyrgyzstan is indirectly linked to the world financial markets 
through banks with Kazakhstan capital. Thus, the banking system of Kyrgyzstan is indirectly affected by Global Financial Crisis indirectly through deteriorations in the banking system of Kazakhstan. In the second half of 2009, banking lending activity in Kyrgyzstan has significantly decreased, as Kazakhstani banks had the largest share in the bank loan portfolio. Moreover, proportion of non-performing loans is increased mainly due to reductions in trade, remittances and banking loans (Ruziev \& Majidov, 2013; Engvall, 2016).

The deterioration of the macroeconomic situation, caused by the internal social and political destabilization in April and June 2010, exacerbated the negative impact of the global financial crisis. After the scandalous events associated with the bankruptcy of the systemically important financial institution, Asia Universal Bank (AUB), and other related banks showed insufficiency of a banking supervision and regulation in the identification of risks and unlawful acts in commercial banks. Political events of 2005 and 2010 also seriously hindered the intermediation activity through reducing volume of attracted deposits (Ryskulov, 2010: 103; EBRD, 2011; Coleman et al, 2012: 56; Global Witness, 2012). Corruption, corporate raids, informal links, insecure property rights, weak legal environment and interferences by some politicians and state officers make investment environment in the banking sector as unfavorable (Engvall, 2016).

Despite the liquidity support provided by authorities to the banking sector, the desired outcomes have not been achieved with regard to the lending rates and volumes. Quality of assets decreased indirectly because of high dollarization of the banking sectors' balance sheet (Mitra, 2010: 220). Positive trends in the economy were not accompanied by an improvement in the indicators of the banking sector in 2011. 2012-2014 can be defined as a period of gradual recovery of the banking system after disturbances in previous years (IMF, 2016).

\section{Global Prices of Energy Resources and Regional Instabilities: 2014-2016}

The dependence and vulnerability of the Kyrgyz economy from the economies of neighboring countries such as Russia and Kazakhstan are always maintained (Abazov, 1999: 198, 201, 206; Siegoelbaum et al, 2002: 6; Mitra, 2010: 219). The macroeconomic environment in Russia and Kazakhstan largely depends on the changes in world oil and gas prices.

Sanctions imposed against Russia by Western countries and decline in world prices for oil and other natural resources in 2014 caused capital outflows from Russia, therefore devaluation of Russia's ruble. Due to dependence on the Russian economy, economy and the banking system of the Kyrgyzstan also were negatively influenced from these instabilities (Dreger et al, 2016; Yadav, 2016). Exchange rate volatility in 2015-2016, due to the deterioration of the macroeconomic environment in the CIS countries and in the world economy worsened quality of the loan portfolio of commercial banks in Kyrgyzstan. 
Against to instabilities of foreign exchange rates in 2015-2016 the NBKR has taken appropriate prudential regulatory measures to reduce systemic risks and vulnerability of the financial sector to external shocks. In accordance with these measures, banks were encouraged to attract deposits and issue loans in national currency instead of foreign currency. Due to which average level of dollarization of deposits and loans decreased in 2016 compared to 2015 from $65.5 \%$ and $54.6 \%$ to $59.8 \%$ and $45.6 \%$, respectively. Moreover, since May 7, 2015 NBKR introduce selling of refined gold bullions with high liquidity. The purpose of these regulatory actions was to create a precious metals market and offer alternative savings and investment instruments for the US dollar for the population and enterprises. The introduction of a new instrument in circulation has led to a decrease in dollarization in the banking sector, on the other hand (NBKR, 2016).

After political destabilization in April of 2010, Manas Bank, Investbank Issyk-Kul, Kyrgyz Credit Bank and Akylinvestbank were identified as problem banks, and their activities were limited by the regulator and supervisor by introducing a conservation regime. In 2011, after the change of ownership and capitalization Akylinvestbank was renamed to Capital Bank. Restrictions on the banking activity of Kyrgyz Credit Bank were terminated in December 2014 and later was renamed to Eurasian Savings Bank in 2016. Manas Bank and Investbank Issyk-Kul were operated in the preservation, conservation regimes until their licenses were abolished in 2015 due to their insolvency.

Getting of the largest former micro financial institutions banking licenses can recognized as other tendency of recent years. Namely, Bai-Tushum, MCC FINCA and MFC Financial Group Companion transformed into Bank Bai-Tushum, FINCA Bank and Companion Bank in 2012, 2015 and 2016, respectively. After obtaining banking licenses, they are allowed lend in foreign currency, have access to financial resources provided by the NBKR. Another financial institution achieved banking license was de novo bank, Chang An Bank, created in 2015. The Kyrgyz-Swiss bank was created through the rehabilitation of the Kyrgyzdyikanbank and the capitalization carried out by investors from Switzerland in 20132014. In these years Zalkar Bank was purchased by the Russian investors and renamed to Rosinbank. Change in the name of banks was mainly due to changes in the owners and associated with the rehabilitation and branding of banks. Historical information on changes in the names of 25 commercial banks currently operating in Kyrgyzstan is presented in Appendix 1. There are two banks which are fully state-owned, RSK Bank and Aiyl Bank. These banks increased their share in banking sector portfolio in recent years.

Banks still retain a dominant role in the financial system of Kyrgyzstan. Ratio of banking assets, loans and deposits to GDP were increased in recent years and observed at $41 \%, 21.2 \%$ and $21 \%$ in the first half of 2016, respectively. However, the banking system of Kyrgyzstan remains small in comparison with the banking systems of other CIS countries. As showed in Figure 1. liquidity of balance sheets of banks increased from \%65 in 2014 to $75.5 \%$ in 2016. Particularly, the liquidity of medium-sized banks' assets is higher than that of their large and small competitors. After stable decreasing in 2010-2013, share of the nonperforming loans is increased from $4.5 \%$ in 2014 up to $8.8 \%$ in 2016 (NBKR, 2017). Non- 
performing loans chiefly emerged as consequence of exchange rate volatility in trade, construction and mortgage industry.

Figure: 1

Major Indicators of the Banking Sector in Kyrgyzstan (2013-2016, in \%)

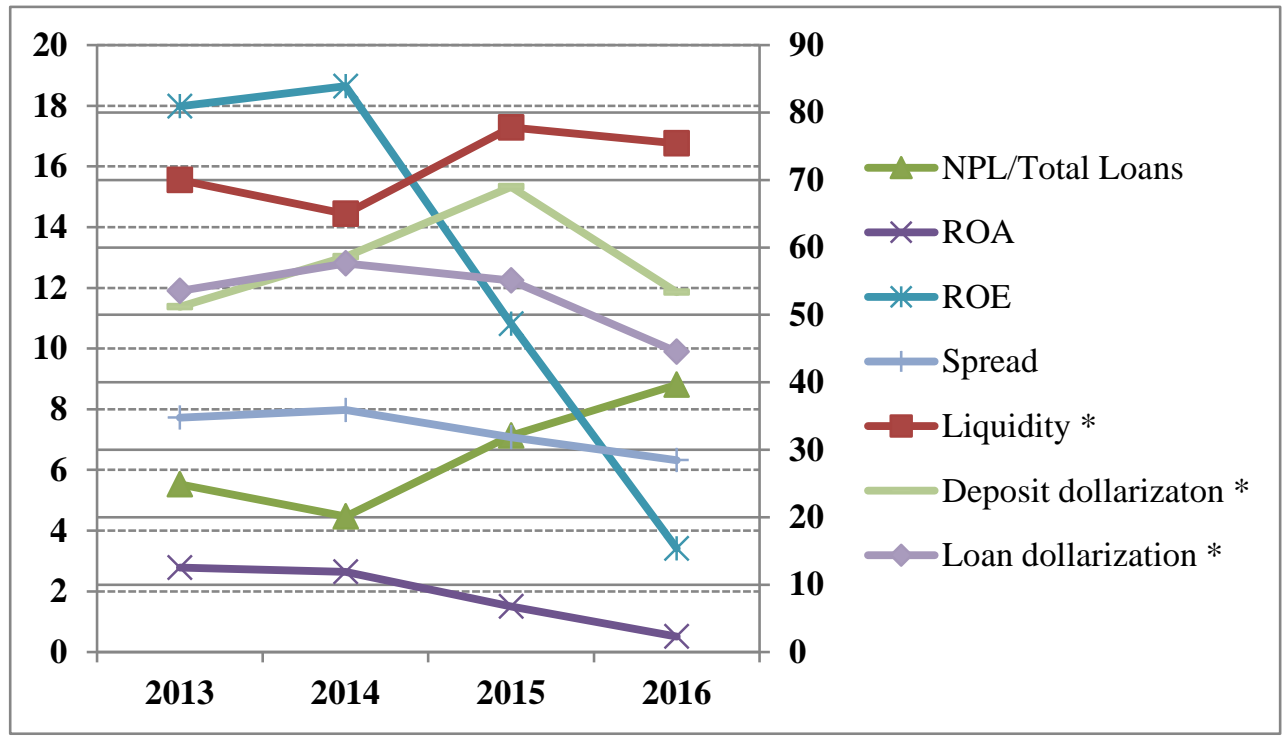

Source: NBKR Bulletin, 2017.

Note: for (*) use second vertical axis.

Average weighted interest rates on both, loans and deposits were observed decreased in 2014-2016. Besides to this banking lending and attracted deposit volume also declined mainly due to restrictions on foreign currency banking loans conducted by NBKR. Declining of spread between lending and deposit rates led to declining of profitability of the banking sector in 2014-2016. Return on equity (ROE) is more sensitive than ROA against to changes in the spread.

Access to banking services in rural areas is limited, as banking activities are concentrated in large cities such as Bishkek, Osh and Jalal-Abad. Banking loans are mainly concentrated in the trade sector and, mainly, were provided by the largest four or five banks. In recent years, there have been no significant changes in the market structure of the banking sector. Largest five banks dominated in the sector hold main part of the banking services market (Ilimbek uulu, 2014; IMF, 2016).

Low financial literacy among the population and SMEs, cash based economy; high costs of operating branches in rural areas also have a negative impact on banking activities and hamper its further development (IMF, 2016). In addition, the problems of digital security and privacy increase the operational and technological risks associated with electronic 
banking services. Therefore, for the further development of the banking system, poor telecommunications infrastructure has become a serious problem that need to be addressed in the near future.

\section{Conclusion}

Structural reforms in the banking system of Kyrgyzstan as a whole were aimed at eliminating the issues caused by macroeconomic instabilities, institutional and infrastructural deficiencies of the banking system itself. Therefore we conclude this study by these aspects. Macroeconomic destabilization in the early stages of the transition, which began in the early 1990s, mainly caused by the transformation process carried out in order to build a market economy. Transformation processes considered wide range privatization and restructuring, disintegration, liberalization and decentralization led to collapse of integrated production and financial system inherited from the Soviet period. As a result of these changes, the quality of the assets of the banking system deteriorated, which subsequently led to the bankruptcy of the largest state-owned banks. As part of these reforms, it was addressed to create a market oriented two-tier national banking system on the remains of the disintegrated mono-bank system existed in the Soviet era. However, these processes aimed at creating institutional infrastructure of the newly created national banking system have led to the fact that banks faced difficult circumstances of activity.

The creation of a market-oriented regulatory and legal and supervisory framework designed to develop and implement market principles and mechanisms in the banking system was not successful. This was mainly due to the old style management inherited from the Soviet era, and the simultaneous lack of market institutions. Moreover, banking institutional problems, primarily conflicts between shareholders and managers, low level of professional skills of bank employees and managers made it difficult to improve corporate governance in banks. Infrastructural deficiencies such as the absence of deposit insurance, debt collection companies and credit bureaus also hindered the further development.

Difficulty of these circumstances can be also explained by painful disintegration processes in CIS region. By the end of the 1990s and the early the 2000s, the impact of external shocks on the part of economically linked neighbors such as Kazakhstan and Russia had begun to manifest itself. A consequence of these shocks for the banking system was the bankruptcy of several banks. Along with this, internal institutional deficiencies in the banking system enhanced the negative impact of external factors. These instabilities contributed to the disclosure of internal institutional shortcomings, especially weaknesses in accounting, auditing and supervision in the banking system. In response to these shortcomings of the regulatory environment in the banking system has been considerably strengthened by the authorities. As response to these inferiorities regulatory environment in the banking system was strengthened significantly by the authorities. This led to the fact that some banks were unable to meet these regulatory requirements.

The introduction of international standards of accounting, banking regulation and supervision in the early 2000's contributed to improving the investment environment in the 
banking sector and, therefore, encouraged the inflow of foreign capital into the sector. The inflow of foreign capital has strengthened competition and entailed the introduction of new technologies in the banking sector, such as internet and mobile banking, ATMs, POS terminals.

The worsening of political and social circumstances in the country were other internal factors that boosted instability not only in the country's economy, but also in the banking system. Despite that banking system of Kyrgyzstan less integrated to global markets it also influenced indirectly from volatilities in the global markets. The global financial crisis, the volatility of world energy prices, geopolitical instability affected indirectly the economy and banking sector of Kyrgyzstan, through macroeconomic instabilities in Kazakhstan and Russia. High banking risks as a consequence of macroeconomic instability, institutional and infrastructural deficiencies have led to an increase in the level of dollarization of banking assets and liabilities. The growth of dollarization has led to greater vulnerability to external shocks of the banking system.

\section{References}

Åslund, A. (2002), "The IMF and the ruble zone”, Comparative Economic Studies, 44(4), 49-57.

Abazov, R. (1999), "Policy of economic transition in Kyrgyzstan", Central Asian Survey, 18(2), 197223.

Baimyrzaeva, M. (2011), “Analysis of Kyrgyzstan’s Administrative Reforms in Light Recent Governance Challenges", International Public Management Review, 12(1), 22-47.

Berglof, E. \& P. Bolton (2002), "The great divide and beyond: Financial architecture in transition", The Journal of Economic Perspectives, 16(1), 77-100.

Bonin, J. \& P. Wachtel (2003), "Financial sector development in transition economies: Lessons from the first decade", Financial Markets, Institutions \& Instruments, 12(1), 1-66.

Brown, M. \& M.R. Maurer \& T. Pak \& N. Tynaev (2009), "The impact of banking sector reform in a transition economy: Evidence from Kyrgyzstan”, Journal of Banking \& Finance, 33(9), 1677-1687.

Claessens, S. (1998), "Banking reform in transition countries", The Journal of Policy Reform, 2(2), 115-133.

Coleman, B.E. \& V. Goffe \& B. Perolli \& M. Usupova \& L.V. Castillo \& H. Holzhacker \& A. Kappeler (2012), "Banking in the Eastern neighbours and Central Asia: Challenges and opportunities", Research Report, Regional Studies and Roundtables, European Investment Bank (EIB).

De Melo, M. \& C. Denizer (1999), "Monetary Policy during Transition: An Overview”, in: M.I. Blejer \& M. Skreb (eds.), Financial Sector Transformation: Lessons from Economies in Transition. Cambridge University Press, 19-92.

Demirguc-Kunt, A. \& H. Huizinga (1999), "Determinants of commercial bank interest margins and profitability: some international evidence", World Bank Econ. Rev., 13(2), 379-408.

Dreger, C. \& K.A. Kholodilin \& D. Ulbricht \& J. Fidrmuc (2016), "Between the hammer and the anvil: The impact of economic sanctions and oil prices on Russia's ruble", Journal of Comparative Economics, 44(2), 295-308. 
European Bank for Reconstruction and Development (2011), Strategy for the Kyrgyz Republic, <http://www.ebrd.com/downloads/country/strategy/kyrgyz.pdf>, 23.08.2016.

Engvall, J. (2016), The State as Investment Market: Kyrgyzstan in Comparative Perspective, University of Pittsburgh Press.

Fries, S. \& A. Taci (2005), "Cost efficiency of banks in transition: Evidence from 289 banks in 15 post-communist countries", Journal of Banking and Finance, 29(1), 55-81.

Garvy, G. (1977), "The Origins and Evolution of the Soviet Banking System: An Historical Perspective", in: Money, Financial Flows, and Credit in the Soviet Union, G. Garvy (ed.), 13-35.

Gegenheimer, G.A. (2006), "Judicial Review of Bank Supervisory Decisions in the Former Soviet Republics: The Case of Kyrgyzstan", Ann. Rev. Banking \& Fin. L., 25, 295-579.

Global Witness (2012), Grave Secrecy: How a dead man can own a UK company and other hairraising stories about hidden company ownership from Kyrgyzstan and beyond, London: Global Witness.

Golodniuk, I. (2005), Financial Systems and Financial Reforms in CIS Countries, Center for Social and Economic Research, Warsaw, July.

Hare, P. \& A. Bevan \& J. Stern \& S. Estrin (2000), "Supply Responses in the Economies of the Former Soviet Union", CERT Discussion Paper, 0009, Centre for Economic Reform and Transformation, Heriot Watt University.

Ilimbek uulu, T. (2014), "Competition in the Kyrgyz Banking Industry: Empirical Study Based on Panzar and Rosse Model", MA Thesis, OSCE Academy, Economic Governance and Development Programme, April.

I.M.F. (2016), "Kyrgyz Republic Selected Issues", IMF Country Report, 16/56, February, Washington, D.C., <http://www.imf.org/en/Publications/CR/Issues/2016/12/31/KyrgyzRepublic-Selected-Issues-43721>, 20.04.2017

International Association of Deposit Insurers (IADI) (2012), "Problem Bank Resolution Methods and Payouts of Insurance Coverage to Depositors of Forcibly Liquidated Banks: Comparative Analysis of Deposit Insurance Systems in CIS Countries", Research Paper, Eurasia Regional Committee, Basel, Switzerland.

Isakova, A. (2008), "Monetary policy efficiency in the economies of Central Asia", Czech Journal of Economics and Finance (Finance a uver), 58(11-12), 525-553.

Jenkins, H. (1996), Financial Sector Review for Kyrgyz Republic”, Discussion Paper, 1996-06, JDI Executive Programs.

Johnson, J.E. (1994), “The Russian banking system: institutional responses to the market transition", Europe-Asia Studies, 46(6), 971-995.

Jumabaeva, G.B. (2000), “Реформа банковского сектора на пороге XXI века”, Реформа, 3(17), 46-48.

Kloc, K. \& R. Woodward (1995), “The Banking System in Kyrgyzstan”, Russian and East European Finance and Trade, 31(6), 73-94.

Kloc, K. (2002), "Banking systems and banking crises in Ukraine, Georgia, and Kyrgyzstan", Problems of Economic Transition, 45(8), 6-71.

Met, O. \& V. Torobekova \& I. Keles (2008), "Financial System Developments in Transition Economies: The Case of Kyrgyz Financial System”, Sosyal Bilimler Dergisi, 19, 1-11. 
Mitra, P.K. (2010), "The Impact of Global Financial Crisis and Policy Responses The Caucasus, Central Asia and Mongolia”, Global Journal of Emerging Market Economies, 2(2), 189230.

Mullineux, A.W. (1988), International banking and financial systems: a comparison, Springer Science \& Business Media.

NBKR, (2001), Annual Report of the National Bank of the Kyrgyz Republic for 2000, April, Bishkek, < http://www.nbkr.kg/DOC/04042005/000000000001195.pdf >, 05.01.2017.

NBKR (2016), Financial Sector Stability Report of the Kyrgyz Republic, National Bank of the Kyrgyz Republic, December, <http://nbkr.kg/DOC/10032017/000000000046200.pdf> , 23.04.2017.

NBKR (2017), Annual Report of the National Bank of the Kyrgyz Republic for 2016, 15 March 2017, Bishkek, <http://nbkr.kg/DOC/28042017/000000000046722.pdf〉, 05.05.2017.

Orozalieva, B. (2015), “Current Account Imbalance of the Kyrgyz Republic”, Dissertation, Central European University.

Pastor, G. \& T. Damjanovic (2003), "The Russian financial crisis and its consequences for Central Asia", Emerging Markets Finance and Trade, 39(3), 79-104.

Pomfret, R. (2006), The Central Asian Economies since Independence, Princeton: Princeton University Press.

Ruziev, K. \& T. Majidov (2013), "Differing effects of the global financial crisis on the Central Asian countries: Kazakhstan, the Kyrgyz republic and Uzbekistan”, Europe-Asia Studies, 65(4), 682-716.

Ryskulov, U.J. (2010), "Political Instability, Revolution: Comparison between Kyrgyzstan and Georgia", Scientific Journal of International Black Sea University, 4(2), 97-112.

Sagbansua, L. (2006), "Banking System in Kyrgyz Republic”, Scientific Journal of International Black Sea University, 1(1), 39-53.

Sherif, K. \& M.S. Borish \& A. Gross (2003), State-owned banks in the transition: origins, evolution, and policy responses, World Bank Publications.

Siegelbaum, P. \& K. Sherif\& M.S. Borish \& G. Clarke (2002), "Structural Adjustment in the Transition: Case Studies from Albania, Azerbaijan, the Kyrgyz Republic, and Moldova", World Bank Discussion Paper, 429, Washington, D.C.

Struyk, R.J. \& F. Roy (2006), “Kyrgyzstan's 'Squatter Communities' and the Potential of Housing Micro Finance to Support Upgrading”, Housing Finance International, 21(1), 22-27.

Tang, H. \& E. Zoli \& I. Klytchnikova (2000), Banking crises in transition economies: Fiscal costs and related issues", World Bank Policy Research Working Paper, 2484.

Tovar-García, E.D. \& R. Kozubekova (2016), "The Third Pillar of the Basel Accord: Evidence of borrower discipline in the Kyrgyz banking system”, Journal of Eurasian Studies, 7(2), 195-204.

Uyanik, T. \& C. Segni (2001), "Evolution of the Banking Sector in Central Asia", in: A. Fleming \& L. Bokros \& C. Votava (eds.), Financial Transition in Europe and Central Asia:

Challenges of the New Decade, World Bank Publications, 97-108.

Vorobey, Y. (2015), “Commercial banking in Kyrgyzstan”, Central Asia Economic Papers, No. 13.

Yadav, R. (2016), "Financial sector reforms and Commercial banks Performance in Kyrgyzstan: 1991-2015”, International Journal of Economics and Research, 7(5), 1-13. 
Aseinov, D. \& K. Karymshakov (2018), "Development of the Banking System in Kyrgyzstan:

An Historical Review and Current Challenges", Sosyoekonomi, Vol. 26(38), 71-86.

Zoli, E. (2001), "Cost and Effectiveness of Banking Sector Restructuring in Transition Economies",

Working Paper, 01/157, International Monetary Fund.

\section{Appendix: 1}

Dates of Establishment and Changes in Names of Commercial Banks in Kyrgyzstan

\begin{tabular}{|c|c|c|c|}
\hline No. & Current Name of the Bank & Date of Establishment or Name Change & Name of Bank \\
\hline \multirow{6}{*}{1} & \multirow{6}{*}{ Optima Bank } & 07.05 .1992 & Kyrgyzmelbiznesbank \\
\hline & & 06.05 .1993 & Kyrgyzenergobank \\
\hline & & December 2001 & Energo Bank \\
\hline & & 14.12 .2006 & ATF Bank - Kyrgyzstan \\
\hline & & 24.12 .2010 & UniCreditBank \\
\hline & & 16.08 .2013 & Optima Bank \\
\hline 2 & Kyrgyz Investment and Credit Bank & 10.07 .2001 & Kyrgyz Investment and Credit Bank \\
\hline 3 & Demir Kyrgyz International Bank & 02.05 .1997 & Demir Kyrgyz International Bank \\
\hline \multirow{4}{*}{4} & \multirow{4}{*}{ Rosinbank } & 1998 & International Business Bank \\
\hline & & 03.08 .2000 & Asia Universal Bank \\
\hline & & 24.12 .2010 & ZalkarBank \\
\hline & & 03.07 .2013 & Rosinbank \\
\hline \multirow{3}{*}{5} & \multirow{3}{*}{ Halyk Bank Kyrgyzstan } & December 1991 & MaksatBank \\
\hline & & 13.04 .1999 & KairatBank \\
\hline & & 30.12 .2004 & Halyk Bank Kyrgyzstan \\
\hline \multirow{3}{*}{6} & \multirow{3}{*}{ Kyrgyzkommertsbank } & 13.12 .1991 & Kyrgyzavtobank \\
\hline & & 19.12 .2002 & Kazkommertsbank Kyrgyzstan \\
\hline & & 27.05 .2015 & Kyrgyzkommertsbank \\
\hline 7 & Bank Asia & 10.02 .1998 & Bank of Asia \\
\hline 8 & Bishkek branch of the NBP & 24.04 .2000 & Bishkek branch of the NBP \\
\hline 9 & FinanceCreditBank KAB & 30.01 .2006 & FinanceCreditBank KAB \\
\hline \multirow{2}{*}{10} & \multirow{2}{*}{ RSK Bank } & 22.07 .1996 & RSK \\
\hline & & 03.10 .2008 & RSK Bank \\
\hline \multirow{4}{*}{11} & \multirow{4}{*}{ Aiyl Bank } & 01.01 .1988 & Agroprombank of USSR \\
\hline & & December 1991 & JSC “Kyrgyzagroprombank" \\
\hline & & 03.07 .1997 & Kyrgyz Agricultural Financial Corp. \\
\hline & & 27.12 .2006 & Aiyl Bank \\
\hline \multirow{3}{*}{12} & \multirow{3}{*}{ Commercial Bank Kyrgyzstan } & 01.01 .1988 & Zhilsozbank of USSR \\
\hline & & 06.11 .1990 & AKB Kyrgyzstan \\
\hline & & 20.11 .2006 & Commercial bank Kyrgyzstan \\
\hline \multirow{3}{*}{13} & \multirow{3}{*}{ EcoIslamicBank } & September 1996 & Rossiyskiy Credit \\
\hline & & 10.03 .1998 & EkoBank \\
\hline & & 16.07 .2010 & EcoIslamicBank \\
\hline \multirow{3}{*}{14} & \multirow{3}{*}{ BTA Bank } & 29.11 .1996 & AKB Eridan \\
\hline & & 08.05 .2001 & CJSC Ineximbank \\
\hline & & 17.03.2008 & BTA Bank \\
\hline \multirow{2}{*}{15} & \multirow{2}{*}{ Amanbank } & 17.05.1991 & Ak Niyet \\
\hline & & 16.11 .1995 & Amanbank \\
\hline 16 & Dos-Kredobank & 18.06 .1997 & Dos-Kredobank \\
\hline \multirow{2}{*}{17} & & 29.12 .1998 & Bank-Bakai \\
\hline & Bakaibank & 13.01 .2012 & Bakaibank \\
\hline 18 & Tolubai & 24.01 .1996 & CJSC AKB “Tolubai” \\
\hline 19 & Eurasian Savings Bank & $\begin{array}{l}17.11 .1998 \\
28.03 .2016\end{array}$ & $\begin{array}{l}\text { Kyrgyz Credit Bank } \\
\text { Eurasian Savings Bank }\end{array}$ \\
\hline & & 30.10 .1995 & Akyl \\
\hline 20 & Capital Bank & February 2009 & OJSC "AkylInvestbank" \\
\hline & & 30.08 .2013 & Capital Bank \\
\hline 21 & & 07.05 .1992 & Kyrgyzdyikanbank \\
\hline 21 & Kyrgyz-Swiss Bank & 23.01 .2014 & Kyrgyz-Swiss Bank \\
\hline 22 & Chang An Bank & 07.10 .2015 & Chang An Bank \\
\hline 23 & Bai-Tushum \& Partners MF Bank & 13.11 .2012 & Bai-Tushum \& Partners MF Bank \\
\hline 24 & FINCA Microcredit Bank & 03.03 .2015 & Finca Microcredit Bank \\
\hline 25 & Kompanion Bank & 12.01 .2016 & Kompanion Bank \\
\hline
\end{tabular}

Source: Kloc \& Woodward (1995), Zoli (2001), Jenkins (1996), Annual Reports of the National Bank of the Kyrgyz Republic for 1995-2015 years. 